\title{
Problems and tensions in the educational and formation field
}

DOI: https://doi.org/10.32870/dse.v0i12.265

José Luis Martínez Rosas*

(Trad. Marcela Suárez Essport)

The beginning of the constitution of education as a field of knowledge can be set up in an arbitrary manner in Juan Amos Comenio's pioneer work back in the Sixteenth Century. Ever since, this has been a field subject to tensions and problems. Some of it elements are, and should be, submitted to an extended debate in the light of the contemporary requirements and conditions.

In a far from exhaustive enumeration the elements listed below have been the object of critical analysis and debates.

1. The categories of schools: modern, traditional, active and even deschooling itself; as well as the character of its subjects: passive or active

2. The relation among "the educational", "education" and "schooling"

3. The objectives and the meaning of education and formation

4. The primacy of the cognitive, social or moral aspects in the formation processes

5. The denomination of the field: education, pedagogy, educational science or siciences of the education

6. The epistemological status of the discipline: is it in effect a discipline? Or a field of social practices? Or a body of professional or scientific knowledge?

7. The existence of a theoretical object of the field itself and of some specific research method for its study, as well as the relations among the theoretical, the meta-theoretical and the epistemic discourses

* Educational Sciences Doctorate. Professor in different universities. Member of the Investigation on Formation and Post Grade Consulting Network in Mexico. E-mail: joseluismar444@hotmail.com 
8. The scope of relative autonomy of this field in the face of others, as well as the inter-field relations

9. The degree of permeability of this social space and the characteristics of its internal construction, as well as the norms, demands and the type of capital required for the exercise of the professions of the field, teaching among them.

10. The relationship among educational projects, nation projects, state-nation projects or post-national states, as well as the contribution of education to the economic and social development or the abatement of socioeconomic asymmetry

11. The characteristics and relationship between theory and practice: teaching, management, research, etc.

12. The hegemonic or subordinated relations among the different practices, e.g. the role of educational teaching and research; the function of teaching vis a vis the knowledge made available by the hard sciences or the humanities: transmission, interpretation, transformation of the scientific objects in teaching objects, etc.

13. The tensions and nexus between education and culture and between homogeneity and cultural diversity

14. The relations among social, economic, political and educational actors, national as well as global, and the nature of the educational reforms

The above issues are just examples that allow us to perceive the multiple and very important issues of the debate, which is necessary in order to understand the complexity of the field and to evaluate the great diversity of aspects than can be the object of criticism and debate. In this order of ideas, we want to emphasize that the object of this work is expediting the dialogue between author and reader to generate successive questionings and expand the inter-subjectivity framework in order to enable a future symbolic strategic action among a growing number of associates. We therefore invite the reader to focus in the homogenization of two components of the educational space which have an impact in the formation processes: the school and the curriculum.

\section{Tensions and requirements in the school system}

Schooling education is made-up by different levels, among which are: a) the school institution with its organization, its infrastructure, equipping and other components of greater complexity; b) the curriculum; c) the teaching approach; d) the educational practices and the pedagogic resources; e) the subjects of the educational act, and f) other social subjects. 
It is often claimed in teaching circles that education has not changed for centuries; however, the schooling education has undergone highly visible changes in its different levels since the advent of capitalism and the modernity. At present, the nature of the school environment -cultural, political, scientific, socializing, and moralizing- has been brought into question, criticized from positions defined as "neoliberals", with the object of befitting the educational institution to the global educational agendas and the educational projects of the State-nations in transit to post-national States. In light of this criticism, the whole body of formal education and the school institutions is in a difficult situation, under demands, tensions and adjustments that do not satisfy the leading circles of the national educational systems, the organizations in charge of the meta-national processes or other actors in the process, such as entrepreneurial directors.

In the last decades the school education has been through a variety of reform processes with the object adapting it to the environment, whether reorganizing the system or moving it towards a greater quality. At the beginning of the second decade of the twenty first century those changes have derived in a progressive homogenization of the school institution as well as of the curriculum and, at the same time, in a standardization of the evaluation so that the similar characteristics of these three entities can be recognized in different parts of the world.

The homogenization, which in this case is applied to the school institution and the curriculum, derives from the Latin term homogenéus and refers to the subject or entity which belongs to the same gender or group, shares elements or characteristics equal or uniform (RAE, 2014). However, homogeneous does not imply forgetting that, besides what is equal and uniform there are elements of differentiation that confer specific characteristics to the schools and the curricula.

Criticism of the limitations of education coming from organizations like the Organization for Economic Cooperation and Development (OECD) is meant to subordinate and subsume the school institution and the curricula to the neoliberal agenda, and homogenize its basic characteristics.

Considering the above, it is relevant to debate and review this project in order to promote a diversity of educational projects and alternative schools and curricula suited to the different projects of culture, society and economy that might exist.

\section{Homogenization of the model of the teaching institution}

From the end of the Middle Ages, generally associated with the fall of the Byzantine Empire in 1453 or the discovery of America in 1492 and the configuration of the modern capitalistic WorldSystem itself, two great periods in the historical development of the teaching institution can be delineated: those of the traditional school and the modern school.

According to Palacios (2007) the traditional school was instituted in Europe during the seventeenth century with the boarding schools and to a great extent as a result of the success of the ones ruled by the Jesuits. The principal features of this school model, method and order according to Jesús Palacios, were systematized by Comenius in his Didactica Magna published in 1657. 
At least two variants of the traditional school were developed, the boarding schools and the reformed traditional school.

For the most part, the day to day life in boarding schools was a lesson in moral. The boarding schools were characterized by their segregation from the world and a steadfast surveillance of pupils (Snayders, cited in Palacios, 2007); the content of their instruction was the return to antiquity, Latin the everyday language, instruction and learning were based on the art of rhetoric (Mesnard, 1974) and a competitive system between Greeks and Carthaginians with followers in each band; the group of pupils were hierarchically organized in magistrates, decurions and other categories; the professor organized the life and activities of the boarding school and monitored the observance of the established rules.

The reforms to the traditional school propelled by Comenius and others in Europe included the use of native language instead of Latin; the incorporation of profitable knowledge and universal schooling provided by the State for men, women, poor and rich.

The modern school welcomes the legacy of modernity, as opposed to the old and Medieval Ages which dominated the European scene until the fifteenth century and the first half of the sixteenth century. The typical modern school befitted the era of the industrial revolution, bringing on high and firm expectations, in the belief that a general formation close to humanities was feasible and that middle school had a propaedeutic function in the teaching of sciences and in the formation for work (Gonzalez, cited in Palacios, 2007).

The ideology of modernity includes: a public sphere structured by the notion of citizenship and the nation-state as a guarantor of the rights and duties of individuals; the impulse to capitalist production, commercialization and the conquest and establishment of colonies; development of thought and rationality linked to the deployment of sciences and disciplines; questioning of the prevailing hermeneutical system in religious matters and the rise of Protestantism and the religious reform, among other elements associated to such events as the invention of printing and the discovery of America. According to Michel Foucault (1986) the modern school is a power, knowledge and training device to instill in students the required discipline for the development of the capitalist rational and logic thought.

Martha Souto refers to modern school acts as a mechanism which, from Foucault's perception, is considered "a network that links a set of heterogeneous elements in an interplay of power and knowledge relations with a strategic objective (Souto, 1999:70) and, as such, understands surveillance, control, discipline and even punishment as elements that enable their strategic character on what concerns the desire and hope of social emancipation

We perceive the modern school not only as a device but also as an institution of a strictly symbolic character that settles norms and values, in this case, enhancing the codes of high culture, knowledge and written transmission through the books whose serial publication is made possible by printers, to the degree that teacher and book represent knowledge and power. In short, it is the 
school of rationality and illustrated thought mandated by the development of natural and social sciences.

The diverse variables of the new school, whose origins date back to Rousseau, express the different emphasis acquired by one or more of the mentioned features in the proposal of every pedagogue; Cousinet focuses on teamwork; Freinet on the exploration of the environment, printing and the text; Claparede and Dewey, each one in his own way, try to further a functional education, Dewey emphasizes the democratic character of education, even renovating the school as workshop or laboratory. Makarenko, himself excluded by many of the pedagogic saga of the new school, works on discipline, emulations and inculcating collective values, among others.

From all these proposals a unified model of school institution gradually emerged to be shared by the nations, with their particular differentiations, even by the factions at war in the different independence conflicts in olden time colonies and later in civil wars. Seen from afar, it was a process of unity in diversity, in which the school institution as we know it today unfolds itself historically.

There is no doubt that the contemporary perception of a more or less homogeneous model for each one of the three educational cycles (basic, secondary and superior) is still impregnated by those characteristics, the basic education segment seeming more homogeneous and the superior one more diverse. It can even be stated that the Extended Basic Education (EBE), which is projected through part of the secondary education by including generic competences, refines and delineates what today is expected across the planet in relation to an individual who has sufficient minimum elements to act in globalized contemporary society. The (EBE) has a negative balance in relation to these requirements and expectations, but it also shows its own limitations.

On what concerns secondary education and according to Santos del Real (2000), young people are aware that the certificate of secondary education and studies beyond this level are necessary but insufficient to access or improve their occupational status condition. Moreover, young people of secondary school age associate teacher performance to their liking of learning and their perception of the relevance of school content. This set of situations adds to the requirements established by the globalized context to this educational level so, not only a change in these schools is required but also a change in their educators.

This can be read as a sign that the present modern school has been eroded and has lost effectiveness in the constitution of subjectivity required by the conditions of the current context. But it seems like the void generated by the lack of efficiency is covered by another feature of the homogenized model: the progressive commodification of school.

Commodified schools are a sign of our times. The World Bank establishes school autonomy among its most prototypical proposals. This has largely been interpreted not only as management autonomy but rather as a detachment of the school from its State character, thus leading to a new kind of contract as private enterprise with its clients, whether pupils and/or pater familias.

The ideology of modernity, sometimes fought-off, sometimes subsumed in the neoliberal thinking shared the luck of modern schools, conceived as a device for the formation of subjects in 
agreement with modernity, has been changed, thanks to homogenization, into a highly efficient device to instill in the minds, bodies and hearts of subjects the performative features mandated by the neoliberal thinking.

Is this homogenized and homogenizing device at all capable of preserving and developing the great diversity of cultural, economic, political and social options of humanity? Obviously not!

\section{Curricula homogenization}

As well as we have tried to look beyond education, formation and the school, we must now look through the curriculum. There is no doubt that the curricular reforms considered as third generation ones, along with those that focused on educational planning, evaluation and management, accou$\mathrm{nt}$ for a stretch of the cultural history and not only of the educational history; cultural history is a term belonging to the larger historical field which takes into consideration the linguistic deflections in social and historical studies (Popkewitz, Franklin and Pereyra (2003). The ultimate concern is about the rational systems that put in order and classify the objects of schooling (the notions of childhood, school subjects, learning and teaching theories). The objective in the curriculum is to emphasize knowledge and reasoning in schools -the forms through which we "tell the truth" about ourselves and about others- as the basis to understand the formation of modern schooling.

In this order of ideas, changes in the space of curricular theory and in the curricular reforms themselves can be considered as changes in cultural history. The main categories that have supported the curricular proposals associated to modern school are three: formation, learning and competence, and particularly competence, which is associated to the neoliberal thinking and the development of school as a performative device.

In the context of the period of modern culture and imperialist capitalism of the Cold War Era, when dialectic and peripheral-centers of the culture-world and the economy-world seem to be the most visible tension, the word "competence" appears with a leading role. According to De Ketele (2008) "competence" is a "badly defined concept, not clear enough and epistemologically questionable" but which has caused knowledge to be presently considered "not as possessing information but as being competent to solve ambiguous and changing problems" (Rodríguez, cit. at Navarro Leal 2010). In the face of this mandate, school as a device is both more necessary and more insufficient (Filmus and others, 2001), thus facing greater challenges.

Associated with neoliberal globalization and the economy of knowledge, the first and second generation educational reforms further the quality politics (planning, accountability, evaluation, certification and accreditation) are, at a world level, inspired by the approach in competences (Diaz-Barriga, 2011). The relevance of this category is such that it has progressively come to constitute the backbone of curricular reforms and is articulated to a more generic discourse on the characteristics of education in times of globalization, thus becoming a narrative that configures "the educational" and transforms the original meaning of integral formation into what Lyotard calls "performativity". 
The categories of learning and formation were diversely affected when, at the end of the twentieth century, the category "competence" coming from the fields of economy and administration, took a leading and articulating role in the discourses of educational policies and academic and educational knowledge, gaining a central position in the construction of the curriculum and, finally, in provoking the detonation, dislocation or annulation of the "integral formation" category and the subsumption of the "learning" category (Martinez, López and Carpio, 2013).

The emergence of education based on competence standards in the United States around 1930 is the most remote record related to the genesis of the arisen from the economic field "competence" category (Argüelles, 1006; Gonczi, 1996). In relation to this, according to Mexico's National Council for Standardization and Certification of Occupational Competences (SEP/CONOCER, 2008):

An occupational competence is an individual's productive capability, which is defined and measured in terms of performance in a particular occupational context and not only in terms of knowledge, skills and attitudes; these are required but not sufficient in themselves for an effective performance.

A second moment in the development of this category as vertebral axis of the curriculum is the subscription of the Bologna Treaty and the creation of the European Space for Higher Education by the education ministers of twenty one countries of the European Union in 1999. This treaty is orientated towards the homologation of careers and titles through the credits system and the standardization of descriptive letters in the curriculum of careers; all this with the object of facilitating the free transit of professionals and students among the countries of the Union.

Immediately after, in 2000 and 2001, the Organization for Cooperation and Economic Development (OCDE) promulgated the Definition and Selection of Competences (DeSeCo), a key document for the dissemination of this category in the national educational systems of the member countries. This document is installed and filtered through the norms and national educational programs, in particular through the design and regular application of the PISA test in to evaluate competences of fifteen year old youths and ensure the compliance of national systems and schools with the mandate of the neoliberal agenda as performativity devices.

The development of the Tunning Project for Europe in 2001 and for Latin America in 2004 ushers in the next stage in the deployment of the category competence, one of its objectives being the curricular design for superior studies in different professions based on this approach. Mexico is member of the latter project, which has led since 2012 to apply the competence approach as centerpiece in curricular design at all educational levels.

As can be observed, capacity building in the occupational sphere based on competence standards, initially meant to supplement what workers had learnt in educational institutions, has now grown into an articulating approach in curricular design not only along the United States but also the European Union and Latin America, even though different stages are recognized in the process of its installation and sedimentation as the centerpiece in the curricular space 
The "formation" category, which refers to the process of acquisition of culture of the spirit, capability of ethical and esthetical judgement, wisdom and science, common sense and rationality, practical knowledge, and ideal of the sage and the savant which synthetizes the meaning of "humanity" has been moved over. (Gadamer, (1991.1992). However, there is some continuity in the emphasis that formation has had in the Anglo-Saxon world understanding it as professionalization. This emphasis has been inherited as can be appreciated from two essential definitions of what competence means for the European Union and the OCDE.

The European Union's document Education and Formation defines a competence as "a multifunctional and transferable package of knowledge, skills and attitudes that every individual requires for his realization, personal development, inclusion and employment".

While in the DeSeCo Report OCDE (2001) establishes that:

Competence is the capability to respond to complex demands and execute them in an adequate way. It entails a combination of practical abilities, knowledge, and motivation, ethical values, attitudes, emotions and other social and behavior components which mobilize jointly to achieve an efficient action.

In both cases it refers to a group of capabilities and actions that come into play in life situations not necessarily related to educational institutions, thus obtaining their performative character proving that a person acts or performs in an adequate manner according to the requirements of the circumstances.

It is precisely the requirement of an efficient performance that establishes the greater difference with the acquisition of the culture of the spirit, inasmuch as a profound and solid formation in fields of knowledge not necessarily important in "performance" tend to be left out in the educational processes based on competences. Back in 1990 Gimeno Sacristán had already analyzed the way in which the approach of "performance by objectives" -very similar to this new "performance pedagogy"- was obsessed with efficiency in educational results; that is, with the vision of learning from a technical rationality, more concerned with the use of resources than with the formation processes.

The revocation of the "formation" category is the sign of an emphasis on the instrumenting of education and eventually on its subordination to the requirements of the economic world through competitiveness and a system of values (De la Torre, 2004) closely tied to philosophic pragmatism and economic neoliberalism. A form in which this condition is expressed is the loss of importance of formation in philosophy and epistemology in post master education in Mexico in the decade 2002-2012 (Pérez, Limón and García, 2013).

In spite of the weak theoretical consistency of competence approaches (Moreno Olivos, 2009), the last generation of educational reforms in Mexico and the world have been made following this position (Díaz Barriga, 2011). This has been reported in several studies; Lugo and collaborators's 
(2008) for example, document and analyze the form in which Mexican superior education has gone from educational reforms to curricular innovation and intervention in educational practices from the competences approach; while Barrón (2009) presents the development of competence based curricula as an innovating educational project in Mexican superior education. The Secretaria de Educación Püblica (Mexican Secretariat of Public Education) (SEP, 2008 and 2011) has also made in recent years some competence based reforms to the educational projects of basic, secondary and superior education. Furthermore, in post master education, philosophy formation and educational theory have lost relevance in the face of competences formation (Pérez Arenas, 2007).

\section{Final words}

Through the different moments and geographies briefly visited here our objective is to emphasize the fact that the current tendency in Mexico, Europe or the United States leads to homogenizing curricula based on a technical rationality.

The school associated to the emerging project of capitalism and modernity subsequent to the Middle Ages has been disturbed by trying to turn it into an efficient performative device associated with neoliberal thinking.

The curricular design and the educational institutions are going through continuous adjustments and reforms which are part of a general process of homogenization whose objective, no doubt, is to find alternate ways of education and formation and at the same time inhibiting the diversity of cultural and social options which are in conflict with the so called neoliberal globalization.

\section{Referencias}

Arguelles, A. (comp.) (1996). Competencia laboral y educación basada en normas de competencia. México: CONALEP.

Barrón, Concepción (2009). Proyectos educativos innovadores, construcción y debate. México, CESU/UNAM.

Comenio, Juan Amós (2000). Didáctica Magna. México: Porrúa.

De Ketele, Jean Marie (2008). "Enfoque socio-histórico de las competencias en la Enseñanza”. En: Profesorado. Revista de currículum y formación del profesorado, 12, 3. Recuperado el 15 de mayo de 2014 de: http://www.ugr.es/local/recfpro/rev123ART1.pdf

De la Torre, Miguel (2004). Del humanismo a la competitividad. México: UNAM/UANL.

Díaz-Barriga, Ángel (2011). "Competencias en educación. Corrientes de pensamiento e implicaciones para el currículo y el trabajo en el aula", en Revista Iberoamericana de Educación Superior (RIES). Vol. II, núm. 5. México: UNAM-IISUE/Universia, [consulta: 17 de febrero 2013].2011). http://ries.universia.net/index.php/ries/article/view/126 
Foucault, Michel (1986). Vigilar y castigar. Madrid: Siglo XXI.

Gadamer, Hans-Georg (1991-1992). Verdad y Método I y II. Salamanca: Sígueme.

Gimeno Sacristan, José (1990). La pedagogía por objetivos, obsesión por la eficiencia. Madrid: Morata.

Gonczi, A. (1996). Instrumentación de la educación basada en competencias. En: Competencia laboral y educación basada en normas de competencia. México: Limusa.

Lugo, Elisa (2008). Reformas educativas, su impacto en la innovación curricular y la formación docente. México. ANUIES/UAEM/Juan Pablos.

Martínez, López y Carpio (2013). "Análisis de la categoría competencia en los currícula de educación básica y media superior en México". Ponencia en el ler. Congreso internacional política, arte y narrativa en las configuraciones de lo filosófico-educativo. México: ATyFE. Memoria en $\mathrm{CD}$.

Mesnard, P. (1974). "La pedagogía de los jesuitas". En: Chateau. Los grandes pedagogos. México: Fondo de Cultura Económica.

Moreno Olivos, Tiburcio (2009). "Competencias en educación superior: un alto en el camino para revisar la ruta de viaje”. En: Perfiles Educativos. Vol. XXXI, núm. 124, 2009, pp. 69-92, Instituto de Investigaciones sobre la Universidad y la Educación. México: UNAM.

OCDE (2005). The Definition and Selection of Key Competencies. Executive Summary (DeSeCo). www.oecd.org/edu/statistics/deseco

Palacios, Jesús (2007). La cuestión escolar, críticas y alternativas. México: Laia/ Coyoacán.

Pérez Arenas, David (2007). Filosofía, teoría e investigación en las maestrías en educación. Un campo sobredeterminado. México: Plaza y Valdez/UNAM ISSUE.

Pérez, Limón y García (2013). "Marginación, exclusión y/o desplazamiento de la formación relacionada con la filosofía, la epistemología y la teoría educativa en los posgrados en educación". En: Orozco y Pontón. Filosofía, teoría y campo de la educación 2002-2011. México, ANUIES/ COMIE.

Popkewitz, Thomas (2008). "Historia del currículum: una anotación breve en la historia". En: Profesorado. Revista de currículum y formación del profesorado, 12, 3, recuperado el 15 de mayo de 2014 de: http://www.ugr.es/local/recfpro/rev113ed.pdf

Barry M. Franklin y Miguel A. Pereyra (coords.) (2003). Historia cultural y educación. Ensayos críticos sobre conocimiento y escolarización. Barcelona-México: Pomares.

RAE (2014). Diccionario de la lengua española, consulta de 25 de mayo de 2014 http://www.rae. es/obras-academicas/diccionarios/diccionario-de-la-lengua-espanola

Navarro Leal (coord.) (2010). Educación Comparada: Perspectiva Latinoamericana. Ciudad Victoria: Sociedad Mexicana de Educación Comparada/Planeación Educación y Asesoría S.A. de C.V.

Rousseau, Jean-Jacques (2005). Emilio o la educación, Madrid: Alianza. 
Santos Del Real, Annette Irene (2000). La educación secundaria: perspectivas de su demanda. México: Universidad Autónoma de Aguascalientes.

SEP (2011). Plan de estudios 2011. Educación Básica. México: SEP.

/CONOCER (2008). Hacia un Sistema Nacional de Competencias de las Personas, que contribuya a la competitividad económica, al desarrollo educativo y al progreso social de todos los mexicanos.

ttp://www.conocer.gob.mx/pdfs/documentos/presentacion_conocer.pdf?view=wrap-per

Souto, Martha (1999). Grupos y dispositivos de formación. Buenos Aires: FFyL-UBA/Novedades Educativas.

Unión Europea (2010). “Education and Training 2010”, The Success of the Lisbon Strategy Hinges on Urgent Reforms. Recuperado de: http://europa.eu.int/comm/education/policies/2010/ et_2010_en.html 